
serta Implikasi

\title{
TINGKAT KECEMASAN SISWA DALAM MENGHADAPI UJIAN SEKOLAH DITINJAU DARI JENIS KELAMIN, JURUSAN DAN DAERAH ASAL SERTA IMPLIKASI
}

\author{
Astri Widya Sari \\ Universitas Negeri Padang \\ Mudjiran \\ Universitas Negeri Padang \\ Alizamar \\ Universitas Negeri Padang
}

\begin{abstract}
This research based on phenomenon that students encounter high level of anxiety in facing Ujian Sekolah (US) such as heart palpitations while following debriefing ujian sekolah, sweat and cold hands while doing 'try out' for US and panic easily about changes of the information regarding US. The research purpose to reveal student's anxiety level in facing US reviewed by gender, major, ancestry and the difference, also the interaction between these variables in determining anxiety level. This research use quantitative method, description comparison type with factorial design. The population is students at SMAN 3 Padang in XII grade. The samples have chosen with cluster random sampling technique and combined with proportional random sampling technique. The instrument is questionnaire with Likert Scale and tested for validity and reliability. The validity test used Product Moment Correlation and the reliability test used Cronbach's Alpha. Data were analyzed with descriptive statistic technique and varian analyzed (ANOVA). The outcomes shows that: (1) student's anxiety levels in facing US reviewed by gender, major and ancestry are in high category, (2) there is difference student's anxiety level between gender, major and ancestry and (3) there is no interaction between gender, major and ancestry in explaining student's anxiety level in facing US. The implication in counseling can be defined with counseling treatment programme in order to decreasing students's anxiety level in facing US.
\end{abstract}

Keywords: Anxiety Level in Facing Ujian Sekolah (US), Gender, Major, Ancestry.

\section{PENDAHULUAN}

Pendidikan adalah bagian yang sangat penting dalam kehidupan manusia, melalui pendidikan dapat membentuk sumber daya manusia yang berkualitas baik dari segi spiritual, inteligensi dan kemampuan. Sekolah merupakan lembaga bagi siswa untuk mengembangkan dirinya secara aktif dan mandiri serta dapat mengaktualisasikan kemampuan serta potensi-potensi yang mereka miliki. Bimbingan dan konseling sebagai bagian dari pendidikan sangat dibutuhkan, karena melalui pelayanan dalam bimbingan dan konseling diharapkan siswa mampu mengatasi permasalahan yang dialaminya serta dapat mengembangkan potensi mereka.

Secara khusus bimbingan dan konseling bertujuan untuk membantu siswa agar dapat mencapai tugas-tugas perkembangannya yang meliputi aspek pribadi, sosial, karir dan belajar. Menurut Prayitno (2009:13) belajar merupakan kegiatan untuk menguasai hal baru yang meliputi 5 (lima) dimensi belajar, yaitu: dari tidak tahu menjadi tahu, dari tidak bisa menjadi bisa, dari tidak mau menjadi mau, dari tidak biasa menjadi biasa dan dari tidak ikhlas menjadi ikhlas. Belajar dalam arti yang luas merupakan perubahan tingkah laku yang meliputi tidak hanya pengetahuan saja, tetapi juga aspek kecakapan, kebiasaan, sikap, pengertian, penghargaan minat dan penyesuaian diri (Uno, 2012:21).
Pada setiap proses kegiatan belajar maka akan ada evaluasi. Evaluasi bertujuan untuk menentukan angka kemajuan atau hasil belajar pada siswa. Evaluasi yang dilakukan dengan baik dan benar seharusnya dapat meningkatkan mutu dan hasil belajar karena kegiatan evaluasi itu membantu siswa dalam meningkatkan cara belajarnya. Akan tetapi, pada kenyataannya evaluasi yang pada setting sekolah adalah ujian menimbulkan kecemasan pada siswa. Ujian Sekolah (US) merupakan salah satu cara pemerintah untuk meningkatkan mutu pendidikan Indonesia. Wafiq (2014:1) menyatakan Ujian Sekolah (US) adalah kegiatan pengukuran pencapaian kompetensi peserta didik yang dilakukan oleh satuan pendidikan untuk memperoleh pengakuan atas prestasi belajar dan merupakan salah satu persyaratan kelulusan dari satuan pendidikan.

US dapat dikatakan sebagai "momok" yang menakutkan, hal ini dikarenakan pada US materi yang diujikan jauh lebih banyak dibandingkan pada saat ujian nasional. Hasil ujian nasional saat ini tidak lagi menjadi penentu kelulusan siswa dalam menempuh ujian akhir. Sekolah akan memiliki wewenang $100 \%$ dalam menentukan kelulusan siswa.

Berdasarkan penelitian dari Agustiar dan Asmi (2010:9) bahwa takut gagal dalam ujian akhir dianggap sebagai ancaman bagi siswa yang memicu munculnya kecemasan. Kecemasan dengan intensitas wajar dapat 
dianggap memiliki nilai positif. Namun, kecemasan dengan intensitas yang tinggi dan bersifat negatif dapat menimbulkan kerugian dan mengganggu keadaan fisik serta psikis individu yang bersangkutan. Eysenck, Santos dan Derakshan (2007:336) menyatakan bahwa individu yang berada dalam kecemasan maka akan berusaha mengembangkan strategi yang efektif untuk meredakan kecemasan tersebut guna mencapai kesuksesan. Terlalu cemas menjelang ujian justru akan mengganggu kejernihan pikiran, keinginan untuk belajar, ketangguhan diri dan daya ingat untuk belajar dengan efektif.

Kecemasan menurut Nevid, Rathus dan Greene (2005:163) adalah suatu keadaan aprehensi atau keadaan khawatir yang mengeluhkan bahwa sesuatu yang buruk akan segera terjadi. Kecemasan merupakan hal yang normal dan menjadi bermanfaat apabila dapat mendorong individu, seperti siswa untuk belajar menjelang ujian (Nevid, Rathus dan Greene, 2005:163).

Hurlock (1999:219) menyatakan bahwa kecemasan dapat dipengaruhi oleh beberapa faktor yaitu usia, jenis kelamin, status kesehatan, pengalaman dan besar kecilnya stressor. Penelitian Rana dan Mahmood (2010:65) menyatakan perbedaan jenis kelamin dalam menghadapi kecemasan, khususnya kecemasan dalam evaluasi/ujian, menunjukkan bahwa perempuan memiliki tingkat kecemasan lebih tinggi dibandingkan dengan tingkat kecemasan pada laki-laki. Hal lain yang mempengaruhi kecemasan menurut Slavin (2006:333) adalah mata pelajaran tertentu terutama mata pelajaran yang berhubungan dengan angka-angka lebih menyebabkan kecemasan seperti matematika. Penelitian Rana dan Mahmood (2010:64) juga menyatakan tingkat kecemasan dapat mempengaruhi performa akademik siswa dalam bidang science dan berhubungan dengan angka.

Faktor lain yang juga ikut mempengaruhi kecemasan adalah daerah asal. Daerah asal disini dikaitkan dengan adanya perbedaan budaya dari masingmasing daerah. Hill dan Wigfield (1984:109) menyatakan banyak studi menunjukkan bahwa kecemasan evaluasi merupakan masalah bagi anak dari latar belakang etnis yang beragam, pada anak laki-laki dan perempuan, baik bagi anak dengan kehidupan kelas menengah ke bawah dan anak-anak dari kelas sosial dan budaya yang berbeda.

Data yang diperoleh memperlihatkan bahwa siswa memiliki kecemasan yang cukup besar, seperti tidur menjadi tidak nyaman, jantung berdebar-debar saat mengikuti pembekalan US, tangan berkeringat dan dingin saat mengerjakan try out US serta mudah panik terhadap perubahan-perubahan informasi yang belum pasti kebenarannya mengenai US. Kecemasan yang dialami oleh siswa mengakibatkan siswa menjadi kurang faham mengenai system US, siswa menjadi menghindar dengan tidak hadir saat belajar tambahan tanpa ada alasan yang jelas dan siswa menjadi tidak serius mengikuti pembekalan informasi yang diberikan guru BK mengenai ujian.

Penelitian ini bertujuan untuk melihat: (1) tingkat kecemasan siswa dalam menghadapi US ditinjau dari jenis kelamin yaitu laki-laki dan perempuan serta perbedaannya, (2) tingkat kecemasan siswa dalam menghadapi US ditinjau dari jurusan yaitu jurusan IPA dan jurusan IPS serta perbedaannya, (3) tingkat kecemasan siswa dalam menghadapi US ditinjau dari daerah asal yaitu Minangkabau dan non Minangkabau serta perbedaannya dan (4) tingkat kecemasan siswa dalam menghadapi US jika ditinjau dari jenis kelamin, jurusan dan daerah asal serta interaksi antar variabel dalam menentukan tingkat kecemasan.

\section{METODE PENELITIAN}

Penelitian ini menggunakan pendekatan kuantitatif jenis deskriptif komparatif dengan desain model faktorial. Metode penelitian yang diterapkan dalam penelitian ini adalah ex post facto dengan pengambilan data secara sampling. Rancangan penelitian menggunakan desain faktorial $2 \times 2 \times 2$. Populasi dalam penelitian ini sebanyak 255 siswa kelas XII. Sampel adalah siswa kelas XII yang berjumlah 156 orang yang dipilih dengan menggunakan teknik cluster random sampling dengan kombinasi teknik propotional random sampling.

Tabel 1. Sampel penelitian

\begin{tabular}{|c|c|c|c|c|}
\hline \multirow{2}{*}{ Daerah Asal } & \multirow{2}{*}{ Jurusan } & \multicolumn{2}{|c|}{ Jenis Kelamin } & \multirow{2}{*}{ Jumlah } \\
\cline { 3 - 4 } & & Laki-Laki & Perempuan & \\
\hline \multirow{3}{*}{ Minangkabau } & IPA & 32 & 41 & 73 \\
\cline { 2 - 4 } & IPS & 12 & 13 & 25 \\
\cline { 2 - 4 } & Jumlah & 44 & 54 & 98 \\
\hline \multirow{3}{*}{ Non Minangkabau } & IPA & 19 & 24 & 43 \\
\cline { 2 - 4 } & IPS & 6 & 9 & 15 \\
\cline { 2 - 4 } & Jumlah & 25 & 33 & 58 \\
\hline \multicolumn{2}{|r|}{ Total } & $\mathbf{6 9}$ & $\mathbf{8 7}$ & $\mathbf{1 5 6}$ \\
\hline
\end{tabular}

Instrumen yang digunakan berupa angket dengan model Skala Likert. Uji validitas instrumen menggunakan Product Moment Correlation dengan mean koefisien korelasi 0.609 dan uji reliabilitas menggunakan rumus Alpha Cronbach dengan r 0.955.

Data yang terkumpul dianalisis dengan cara menghitung skor rata-rata tingkat kecemasan siswa dalam menghadapi US. Setelah deskripsi data tersebut, dihitung rentangan data atau interval. Irianto (2010:22) menjelaskan untuk menghitung rentangan data atau interval dapat dilakukan dengan menghitung data tertinggi dikurang data terendah lalu dibagi jumlah kelas, sehingga diperoleh kategori yang diklasifikasikan dengan kriteria pada tabel berikut.

\section{Tabel 2. Tingkat pencapaian responden}

\begin{tabular}{|c|c|c|}
\hline Rentangan & Keterangan & $\begin{array}{c}\% \\
\text { Rata- } \\
\text { rata }\end{array}$ \\
\hline$\geq 186$ & $\begin{array}{c}\text { Sangat } \\
\text { Tinggi }\end{array}$ & $84,5 \%$ \\
\hline
\end{tabular}




\begin{tabular}{|c|c|c|}
\hline 151 sd 185 & Tinggi & $\begin{array}{c}68 \% \\
\text { sd } \\
83 \%\end{array}$ \\
\hline 116 sd 150 & Sedang & $52 \%$ \\
& & sd \\
& & $67 \%$ \\
\hline 81 sd 115 & Rendah & $36 \%$ \\
& & sd \\
& & $51 \%$ \\
\hline$\leq 80$ & Sangat & $\leq$ \\
& Rendah & $35 \%$ \\
\hline
\end{tabular}

(Agus Irianto, 2010:22)

Selanjutnya data yang diperoleh dianalisis dengan menggunakan Analisis Varian (ANOVA).

\section{HASIL DAN PEMBAHASAN}

1. Hasil

a. Deskripsi Tingkat Kecemasan Siswa dalam Menghadapi Ujian Sekolah (US) Ditinjau dari Jenis Kelamin, Jurusan dan Daerah Asal

Data penelitian yang diperoleh untuk deskripsi tingkat kecemasan siswa dalam menghadapi US ditinjau dari jenis kelamin, jurusan dan daerah asal secara berurutan mulai dari yang tertinggi adalah:

- siswa perempuan jurusan IPA Minangkabau dengan rata-rata (mean) sebesar 169.6.

- siswa perempuan jurusan IPS Minangkabau dengan rata-rata (mean) sebesar 160.7.

- siswa perempuan jurusan IPA non Minangkabau dengan rata-rata (mean) sebesar 160.1.

- siswa perempuan jurusan IPS non Minangkabau dengan rata-rata (mean) sebesar 159.8.

- siswa laki-laki jurusan IPA Minangkabau dengan rata-rata (mean) sebesar 156.9.

- siswa laki-laki jurusan IPS Minangkabau dengan rata-rata (mean) sebesar 151.

- siswa laki-laki jurusan IPA non Minangkabau dengan rata-rata (mean) sebesar 151.

- siswa laki-laki jurusan IPS non Minangkabau dengan rata-rata (mean) sebesar 142.1.

b. Hasil Pengujian Hipotesis Anova Berdasarkan Jenis Kelamin, Jurusan dan Daerah Asal Serta Interaksi Antar Variabel

Data penelitian yang diperoleh sebagai hasil dari pengujian hipotesis Anova berdasarkan jenis kelamin, jurusan dan daerah asal serta melihat interaksi antar variabel dalam menentukan tingkat kecemasan siswa dalam menghadapi US dapat dilihat pada tabel berikut.
Tabel 3. Hasil pengujian hipotesis anova berdasarkan jenis kelamin, jurusan dan daerah asal

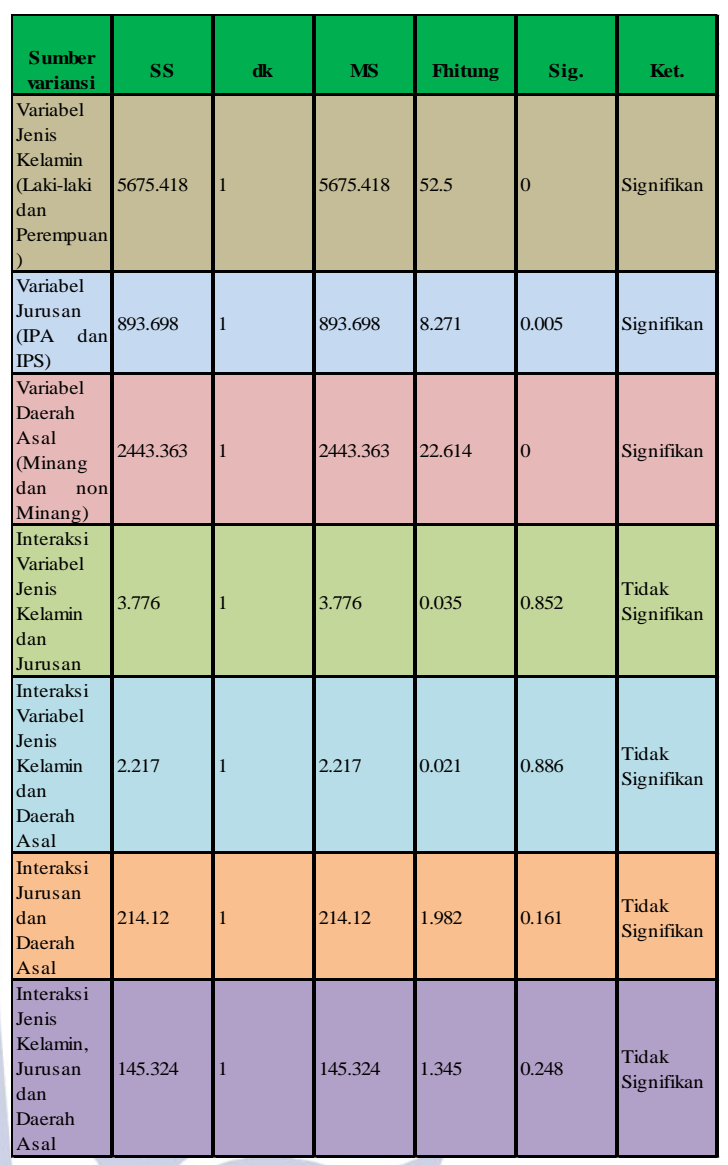

Berdasarkan kepada tabel di atas, maka dapat disimpulkan bahwa:

- terdapat perbedaan tingkat kecemasan siswa dalam menghadapi US antara siswa laki-laki dengan siswa perempuan dengan Sig. 0.000.

- terdapat perbedaan tingkat kecemasan siswa dalam menghadapi US antara siswa jurusan IPA dengan jurusan IPS dengan Sig. 0.005.

- terdapat perbedaan tingkat kecemasan siswa dalam menghadapi US antara siswa Minangkabau dan non Minangkabau dengan Sig. 0.000.

- tidak ada interaksi antara jenis kelamin dan jurusan dalam menjelaskan tingkat kecemasan siswa dalam menghadapi US dengan Sig. 0.852.

- tidak ada interaksi antara jenis kelamin dan daerah asal dalam menjelaskan tingkat kecemasan siswa dalam menghadapi US dengan Sig. 0.886.

- tidak ada interaksi antara jurusan dan daerah asal dalam menjelaskan tingkat kecemasan siswa dalam menghadapi US dengan Sig. 0.161.

- tidak ada interaksi antara jenis kelamin, jurusan dan daerah asal dalam menjelaskan tingkat kecemasan siswa dalam menghadapi US dengan Sig 0.248.

\section{Pembahasan}

1) Gambaran Tingkat Kecemasan Siswa dalam Menghadapi Ujian Sekolah (US) Ditinjau dari 


\section{Jenis Kelamin Laki-laki dan Perempuan serta Perbedaannya}

Hasil analisis data menunjukkan bahwa tingkat kecemasan siswa dalam menghadapi US ditinjau dari jenis kelamin laki-laki dan perempuan sama-sama berada pada kategori tinggi (T). Rata-rata pada siswa perempuan lebih besar yaitu sebesar 164.4, sedangkan pada siswa laki-laki hanya sebesar 152.2. Dari analisis di atas dapat dipahami bahwa siswa perempuan memiliki tingkat kecemasan yang lebih besar dibandingkan dengan siswa laki-laki dalam menghadapi US.

Schunk, Pintrich dan Meece (2008:254) mengemukakan mengenai makna kecemasan "An unpleasant feeling or emotional state that has psychological and behavioral concomitants and that is experienced in formal testing or other evaluative situations". Hurlock (1999:219) menyatakan bahwa kecemasan dapat dipengaruhi oleh beberapa faktor salah satunya yaitu jenis kelamin. Penelitian dari Rana dan Mahmood (2010:65) menyatakan bahwa perbedaan jenis kelamin dalam menghadapi kecemasan, khususnya kecemasan dalam evaluasi/ujian, menunjukkan bahwa perempuan memiliki tingkat kecemasan lebih tinggi dibandingkan dengan tingkat kecemasan pada laki-laki.

Hal ini menunjukkan bahwa perempuan memiliki tingkat emosional yang lebih tinggi dibandingkan dengan laki-laki. Sejalan dengan itu, Beck (2012:1) menyatakan bahwa perempuan cenderung untuk mengalami kecemasan dua kali lebih sering dibandingkan laki-laki. Hal ini dikarenakan secara hormon pada perempuan lebih cepat memunculkan sisi empati. Selain itu, pada perempuan memiliki tingkat 'error-related negativity' yang lebih aktif dibandingkan laki-laki, sehingga perempuan lebih takut untuk berbuat salah dan lebih peka pada situasi yang menurut mereka salah.

Myers (dalam Trismiati, 2004:6) mengatakan bahwa perempuan lebih cemas akan ketidakmampuannya jika dibandingkan dengan laki-laki, laki-laki lebih aktif dan eksploratif, sedangkan perempuan lebih sensitif. Hal ini yang membuat siswa perempuan lebih merasa terbebani menghadapi US dibandingkan siswa laki-laki. Kecemasan yang tinggi dialami oleh siswa perempuan bisa dikarenakan perempuan lebih sensitif termasuk dalam menerima informasi-informasi mengenai hal yang dicemaskan. Menjelang datangnya US terkadang banyak sekali muncul informasi-informasi yang beredar di kalangan para siswa, dimana informasi tersebut belum tentu kebenarannya. Dikarenakan perempuan berada pada posisi yang lebih sensitif, maka siswa perempuan langsung menerima informasi tersebut dan sensitif terhadap informasi yang diterima.

\section{2) Gambaran Tingkat Kecemasan Siswa dalam Menghadapi Ujian Sekolah (US) Ditinjau dari Jurusan IPA dan IPS serta Perbedaannya}

Hasil analisis data menunjukkan bahwa tingkat kecemasan siswa dalam menghadapi US ditinjau dari jurusan IPA dan IPS sama-sama berada pada kategori tinggi (T). Rata-rata skor yang terdapat pada siswa jurusan IPA lebih tinggi yaitu sebesar 160.1, sedangkan pada siswa jurusan IPS hanya sebesar 155.4. Dari analisis di atas dapat dipahami bahwa siswa pada jurusan IPA memiliki tingkat kecemasan yang lebih besar dibandingkan dengan siswa jurusan IPS dalam menghadapi US.

Banyak faktor yang menyebabkan munculnya kecemasan pada setting sekolah, salah satunya adalah materi pelajaran yang diterima oleh siswa. Pada tingkatan SMA siswa akan ditempatkan pada 3 jurusan yaitu IPA, IPS dan bahasa. Jurusan IPA menuntut analisis matematis yang cepat dari siswa. Pada jurusan IPA para siswa berfikir dengan analisis kuantitatif dan banyak materi yang berhubungan dengan angka serta rumusan. Sedangkan pada jurusan IPS para siswa berfikir secara analisis kualitatif dan mata pelajaran yang diterima bersifat sosial. Sejalan dengan pendapat Slavin (2006:333) bahwa kecemasan juga dilihat pada siswa berdasarkan kepada mata pelajaran tertentu, dimana mata pelajaran yang berhubungan dengan angka-angka biasanya lebih menyebabkan kecemasan seperti matematika.

Menurut penelitian Indiyani dan Listiara (2006:2) bahwa dari berbagai bidang studi yang diajarkan di sekolah, maka matematika merupakan bidang studi yang dianggap paling sulit bagi para siswa, baik bagi mereka yang tidak berkesulitan belajar maupun bagi siswa yang berkesulitan belajar. Adanya anggapan bahwa matematika sulit sudah melekat pada siswa, sehingga hal ini dapat memicu kecemasan pada mata pelajaran yang akan lebih banyak dibahas pada jurusan IPA dibandingkan jurusan IPS.

Penelitian dari Rana dan Mahmood (2010:64) juga menyatakan bahwa tingkat kecemasan dapat mempengaruhi performa akademik siswa dalam bidang science dan berhubungan dengan angka. Hasil yang ditunjukkan adalah siswa dengan tingkat kecemasan rendah memiliki performa akademik yang lebih baik dalam bidang tersebut dibandingkan siswa dengan tingkat kecemasan yang tinggi.

3) Gambaran Tingkat Kecemasan Siswa dalam Menghadapi Ujian Sekolah (US) Ditinjau dari Daerah Asal Minangkabau dan Non Minangkabau serta Perbedaannya

Hasil analisis data menunjukkan bahwa tingkat kecemasan siswa dalam menghadapi US ditinjau dari daerah asal Minangkabau dan non Minangkabau samasama berada pada kategori tinggi (T). Rata-rata skor yang terdapat pada siswa yang berasal dari Minangkabau lebih besar yaitu sebesar 160.6, sedangkan pada siswa yang berasal dari non Minangkabau hanya sebesar 154. Dari hasil di atas dapat dipahami bahwa siswa yang berasal dari Minangkabau memiliki tingkat kecemasan yang lebih tinggi dibandingkan dengan siswa yang berasal dari non Minangkabau dalam menghadapi US.

Secara tidak disadari kecemasan terjadi merupakan suatu keadaan yang selalu berkaitan dengan pikiran. Emosi ataupun rasa cemas yang kita rasakan disebabkan oleh adanya dialog internal dalam pikiran individu yang mengalami kecemasan ataupun perasaan cemas. Secara teoretis terjadinya kecemasan diawali oleh pertemuan individu dengan stimulus yang berupa situasi yang berpengaruh dalam membentuk kecemasan (situasi 
mengancam), yang secara langsung/tidak langsung hasil pengamatan/pengalaman tersebut diolah melalui proses kognitif dengan menggunakan skemata (pengetahuan yang telah dimiliki individu terhadap situasi tersebut yang sebenarnya mengancam/tidak mengancam dan pengetahuan tentang kemampuan dirinya untuk mengendalikan dirinya dan situasi tersebut). Setiap pengetahuan tersebut dapat terbentuk dari keyakinan pendapat orang lain, maupun pendapat individu sendiri serta dunia luar.

Skemata tersebut, tentunya akan mempengaruhi individu untuk dapat membuat penilaian (hasil kognitif) sehingga respons yang akan ditimbulkan tergantung seberapa baik penilaian individu tersebut dapat mengendalikan dirinya. Apabila skemata subjek terhadap situasi yang mengancam tersebut tidak memadai, tentunya individu tersebut akan mengalami kecemasan.

Bagaimana individu menilai suatu situasi sesuai dengan kemampuannya, maka pada akhirnya dari penilaian tersebut akan menentukan apakah situasi tersebut mengancam atau tidak mengancam. Apabila penilaian yang dihasilkan adalah dalam keadaan terancam, maka individu akan mengalami kecemasan. Salah satu hal yang mempengaruhi penilaian tersebut adalah bagaimana kondisi lingkungan tempat individu tersebut berada. Pada setting sekolah, para siswa berasal dari latar belakang yang berbeda, salah satunya adalah latar belakang daerah asal. Para siswa berasal dari daerah asal yang beragam dan dapat dikategorikan menjadi daerah Minangkabau (yang berasal asli Minangkabau) dan non Minangkabau (yang berasal dari daerah luar Minangkabau). Dengan keberagaman latar belakang daerah asal, maka yang khas dari keberagaman tersebut adalah budaya masing-masing daerah asal, yang mencakup bahasa dan kebiasaan-kebiasaan.

Hill dan Wigfield (1984:109) menyatakan banyak studi menunjukkan bahwa kecemasan evaluasi adalah masalah bagi anak dari latar belakang etnis yang beragam, pada anak laki-laki dan perempuan, baik bagi anak dengan kehidupan kelas menengah ke bawah dan anak-anak dari kelas sosial dan budaya yang berbeda. Hal ini dapat dimaknakan bahwa keberagaman daerah asal yang dimiliki oleh para siswa dapat menjadi salah satu pemicu munculnya kecemasan.

4) Gambaran Tingkat Kecemasan Siswa dalam Menghadapi Ujian Sekolah (US) Ditinjau dari Jenis Kelamin, Jurusan dan Daerah Asal serta Interaksi Antar Variabel dalam Menjelaskan Tingkat Kecemasan

Dari hasil deskripsi data yang telah dikemukakan sebelumnya, dapat dipahami bahwa ditinjau dari jenis kelamin, jurusan dan daerah asal tingkat kecemasan siswa dalam menghadapi US berada pada kategori tinggi (T). Temuan tersebut juga memberikan gambaran bahwa tingginya kecemasan siswa dalam menghadapi US, dengan kondisi seperti ini sangat dibutuhkan pelayanan dalam bimbingan dan konseling untuk mengurangi tingkat kecemasan siswa dalam menghadapi US.

Gejala-gejala kecemasan yang muncul dapat berbeda pada masing-masing orang. Menurut Priest (dalam Safaria dan Saputra, 2012:55) bahwa individu yang mengalami kecemasan akan menunjukkan reaksi fisik berupa tanda-tanda jantung berpacu lebih cepat, tangan dan lutut gemetar, ketegangan pada syaraf di belakang leher, gelisah atau sulit tidur, banyak berkeringat, gatal-gatal pada kulit serta selalu ingin buang air kecil. Berdasarkan hasil temuan penelitian juga dapat disimpulkan bahwa kombinasi dari variabel jenis kelamin, jurusan dan daerah asal tidak menunjukkan interaksi yang signifikan dalam menentukan tingkat kecemasan siswa dalam menghadapi ujian sekolah. Dengan hasil analisis tersebut memberikan simpulan bahwa semua kombinasi antar variabel jenis kelamin, jurusan dan daerah asal tidak memiliki interaksi ataupun kerjasama dalam menentukan tingkat kecemasan siswa dalam menghadapi US. Maka dapat disimpulkan bahwa terdapat faktor-faktor lain yang lebih memberikan pengaruh terhadap tingkat kecemasan siswa dalam menghadapi US.

5) Implikasi terhadap Bimbingan dan Konseling

Hasil penelitian yang dilakukan terhadap tingkat kecemasan siswa dalam menghadapi US ditinjau dari jenis kelamin, jurusan dan daerah asal sebagaimana telah dijabarkan pada bab sebelumnya menunjukkan bahwa tingkat kecemasan siswa secara umum berada pada kategori tinggi. Hasil ini dapat dijadikan sebagai bahan masukan bagi guru bimbingan dan konseling dan konselor dalam mengatasi tingginya kecemasan yang dirasakan oleh para siswa dalam menghadapi US yang tiap tahunnya akan dihadapi oleh siswa, sehingga dapat memberikan pelayanan yang tepat untuk diberikan kepada para siswa.

Hendaknya pelaksanaan bimbingan dan konseling dapat lebih diintensifkan dan diutamakan baik dalam bentuk orientasi dan sosialisasi maupun implementasi ke dalam bentuk program di sekolah. Oleh karena itu dibutuhkan peran aktif dari kepala sekolah, guru BK, konselor, guru-guru mata pelajaran serta para siswa. Temuan ini dapat menjadi masukan bagi semua pihak sekolah, sehingga tingkat kecemasan siswa yang tinggi dalam menghadapi US dapat diatasi. Pada akhirnya diharapkan dengan memiliki tingkat kecemasan yang rendah para siswa mampu menghadapi US dengan yakin dan percaya diri.

\section{KESIMPULAN}

U Berdasarkan hasil penelitian, dapat disimpulkan bahwa: (1) terdapat perbedaan dengan sig 0.000, dimana rerata skor siswa perempuan lebih tinggi (mean 164.4) dibandingkan siswa laki-laki (mean 152.2), (2) terdapat perbedaan dengan sig 0.005 , dimana rerata skor siswa pada jurusan IPA lebih tinggi (mean 160.1) dibandingkan siswa pada jurusan IPS (mean 155.4), (3) terdapat perbedaan dengan sig 0.000 , dimana rerata skor siswa yang berasal dari Minangkabau lebih tinggi (mean 160.6) dibandingkan siswa yang berasal dari non Minangkabau (mean 154) dan (4) tidak terdapat interaksi antara jenis kelamin, jurusan dan daerah asal dalam menjelaskan tingkat kecemasan siswa dalam menghadapi US. 


\section{IMPLIKASI}

Berdasarkan hasil penelitian dan pembahasan sebelumnya maka implikasi dari hasil penelitian ini dapat diajukan sebagai berikut.

\section{Implikasi Teoretis}

Secara teoretis penelitian ini diharapkan bisa berguna dalam pengembangan kajian psikologis mengenai tingkat kecemasan siswa dalam menghadapi US yang ditinjau dari jenis kelamin, jurusan serta daerah asal.

\section{Implikasi Praktis}

Hendaknya dengan adanya hasil penelitian ini dapat menjadi bahan masukan bagi elemen sekolah bahwa pentingnya pelayanan dalam bimbingan dan konseling untuk mengatasi tingginya tingkat kecemasan siswa dalam menghadapi US dan siswa khususnya diharapkan mampu mengatasi tingginya tingkat kecemasan yang mereka rasakan dalam menghadapi US.

\section{Saran}

Berdasarkan hasil-hasil penelitian, pembahasan dan kesimpulan yang telah dikemukakan, ada beberapa saran yang dapat diajukan sebagai tindak lanjut penelitian ini yaitu.

\section{Bagi Siswa}

Bagi siswa diharapkan untuk aktif dalam mengikuti pelayanan dalam bimbingan dan konseling sehingga para siswa dapat mengetahui mengapa rasa cemas itu muncul, hal-hal apa yang bisa dilakukan dalam menghadapi rasa cemas yang dialami dan mengatasi rasa cemas yang mereka rasakan dalam menghadapi US. Diharapkan pada akhirnya para siswa menghadapi US dengan nyaman dan penuh keyakinan bahwa hal buruk tidak akan terjadi.

\section{Bagi Kepala Sekolah}

Bagi kepala sekolah diharapkan untuk dapat mampu bekerjasama dengan guru $\mathrm{BK} /$ konselor dalam membantu para siswa dalam mengatasi tingginya rasa cemas mereka, sehingga para siswa dapat lebih percaya diri dalam menghadapi US nantinya. Selain itu, diharapkan kepada kepala sekolah untuk mampu memfasilitasi pelayanan dalam bimbingan dan konseling seperti memberikan jam khusus bagi guru BK untuk bisa melakukan kegiatan bimbingan dan konseling baik di kelas maupun di ruang BK dalam usaha mengurangi kecemasan yang dialami oleh siswa.

\section{Bagi Guru BK/Konselor}

Disarankan untuk meningkatkan pelaksanaan program pelayanan dalam bimbingan konseling khususnya untuk mengatasi tingginya tingkat kecemasan yang dialami para siswa dalam menghadapi US sehingga guru BK tidak hanya terpaku kepada administrasi pelaksanaan US dan pendaftaran Perguruan Tinggi saja.

\section{DAFTAR PUSTAKA}

Agustiar, W. dan Asmi, Y. 2010. Kecemasan Menghadapi Ujian Nasional dan Motivasi Belajar
Siswa Kelas XII SMA N "X” Jakarta Selatan. Jurnal Psikologi. 8(1) : 9.

Beck, M. 2012. Anxiety Disorders Diagnosed More Often in Women Than Men. Diunduh di http://wsj.com/health/2012/06/19/anxiety-disordersdiagnosed-more-often-in-women-than-men tanggal 19 Maret 2015.

Eysenck, M.W., Santos, R., dan Derakshan, N. 2007. Anxiety and Cognitive Performance: Attentional control theory. American Psychological Association. $7(2): 336$.

Hartini. 2009. Kesiapan Siswa dalam Menghadapi Ujian Nasional (Studi di SMA Negri Kabupaten Rejang Lebong). Tesis. Padang: Program Pascasarjana UNP.

Hill, K.T. dan Wigfield, A. 1984. Test Anxiety: A major educational problem and what can be done about It. Educational Journal. 85(1) : 109.

Hurlock, E.B. Tanpa tahun. Perkembangan Anak. Terjemahan oleh Meitasari Tjandrasa. 1999. Jakarta: Erlangga.

Indiyani, N.E dan Listiara, A. 2006. Efektivitas Metoda Pembelajaran Gotong Royong (Cooperative Learning) untuk Menurunkan Kecemasan Siswa dalam Menghadapi Pelajaran Matematika. Jurnal Psikologi Universitas Diponegoro. 3(1) : 2 .

Irianto, A. 2010. Statistik: Konsep dasar, aplikasi dan pengembangannya. Jakarta: Kencana Prenada Media Group.

Nevid, J.S., Rathus, S.A., dan Greene, B. Tanpa tahun. Psikologi Abnormal. Edisi 5, jilid 1. Terjemahan oleh Tim Fakultas Psikologi Universitas Indonesia. 2005. Jakarta: Erlangga.

Prayitno. 2009. Wawasan Profesional Konseling.

Padang: UNP Press.

Rana, R.A. dan Mahmood, N. 2010. The Relationship between Test Anxiety and Academic Achievement. Bulletin of Education and Research.

Safaria, T. dan Saputra, N.E. 2012. Manajemen Emosi. Jakarta: Bumi Aksara.

Schunk, D.H., Pintrich, P.R., dan Meece, J.L. 2008. Motivation in Education: Story, research and applications. New Jersey: Pearson.

Slavin, R.E. 2006. Educational Psychology: theory and practice (eight edition). United State: Pearson.

Trismiati. 2004. Perbedaan Tingkat Kecemasan Antara Pria dan Wanita Akseptor Kontrasepsi Mantap Di RSUP Dr. Sardjito Yogyakarta. Jurnal Psyche. 1(1) : 6.

Uno, H.B. 2012. Teori Motivasi dan Pengukurannya. Jakarta: Bumi Aksara.

Wafiq, K. 2014. Pengertian Ujian Sekolah. Diunduh di http:// ujian sekolah/335/wafq/html, tanggal 27 Maret 2015. 